\title{
Hannah Arendt Meets QAnon: Conspiracy, Ideology, and the Collapse of Common Sense
}

David Luban

Georgetown University Law Center, luband@law.georgetown.edu

This paper can be downloaded free of charge from:

https://scholarship.law.georgetown.edu/facpub/2384

https://ssrn.com/abstract=3852241

This open-access article is brought to you by the Georgetown Law Library. Posted with permission of the author. Follow this and additional works at: https://scholarship.law.georgetown.edu/facpub

Part of the Law and Philosophy Commons, Law and Politics Commons, Law and Psychology Commons, and the Social and Behavioral Sciences Commons 


\title{
Hannah Arendt Meets QAnon: \\ Conspiracy, Ideology, and the Collapse of Common Sense
}

\author{
David Luban
}

A whole literature on mass behavior and mass psychology ... [failed to predict] the general contempt for even the most obvious rules of common sense. ${ }^{1}$

Totalitarian propaganda can outrageously insult common sense only where common sense has lost its validity. ${ }^{2}$

\section{§1. Outrages Against Common Sense}

A June 2020 survey found one in four Americans agreeing that "powerful people intentionally planned the coronavirus outbreak." 3 An eighth of Americans younger than 30 thought the culprit is Bill Gates, plotting to create a new world order by implanting mind-control microchips in millions of vaccine recipients. ${ }^{4}$ This theory is revisionism of a kind: a decade earlier, the mastermind seeking world domination was not Bill Gates but George Soros, at least according to a fifth of Americans surveyed in 2011. The 2011 survey also found that about one in five respondents were "truthers" convinced that the 9/11 attacks were an inside job; and a quarter were Obama "birthers." Trutherism, birtherism, and Soros domination plots were three of seven popular conspiracy theories studied, and it turns out that roughly half the respondents believed at least one of them..$^{5}$ In fall 2020,

${ }^{1}$ Hannah Arendt, The Origins of Totalitarianism, $3^{\text {rd }}$ ed. (New York: Harvest Books, 1994) [henceforth OT], 316.

${ }^{2} \mathrm{OT}, 352$.

${ }^{3}$ Katherine Schaeffer, "A look at the Americans who believe there is some truth to the conspiracy theory that COVID-19 was planned," Pew Research Center FactTank, July 24, 2020, https://www.pewresearch.org/fact-tank/2020/07/24/a-look-at-the-americans-whobelieve-there-is-some-truth-to-the-conspiracy-theory-that-covid-19-was-planned/.

${ }^{4}$ Rainer Zitelman, "How Many Americans Believe in Conspiracy Theories?", Forbes, June $29, \quad 2020, \quad$ https://www.forbes.com/sites/rainerzitelmann/2020/06/29/how-manyamericans-believe-in-conspiracy-theories/\#3e2fd9855e94.

${ }^{5}$ J. Eric Oliver \& Thomas J. Wood, "Conspiracy Theories and the Paranoid Style(s) of Mass Opinion," American Journal of Political Science 58(4): 956 (Table 1)(2014); 958 (half of Americans believe at least one of seven theories). The other theories, and their level of support are: the 2003 U.S. invasion of Iraq was not a response to terrorism, but was driven by oil companies and Jews (19\%); the financial crisis of 2008 was engineered by Wall Street bankers to extend the power of the Federal Reserve and further their control of the world's economy (25\%); lingering aircraft vapor trails are chemical agents being 
seven percent in a survey of registered American voters said they believe the elaborate and grotesque mythology of QAnon, which pits Donald Trump against a gang of child-trafficking, Satan-worshipping, blooddrinking leftist elites. Another eleven percent were unsure whether they believe it. ${ }^{6}$ The satanic gang is protected by the Deep State and financed by the ubiquitous Soros. In summer 2020, German QAnon enthusiasts interpreted NATO military exercises as a happy sign that Trump, their superhero savior, would soon invade Germany and free it from Angela Merkel. ${ }^{7}$ November and December 2020 found tens of millions of Americans believing in election-theft plots that would require superhuman levels of coordination and secrecy among dozens, perhaps hundreds, of otherwise-unconnected and unidentified miscreants, with hundreds more covering it up or looking away.

\section{Whatever happened to common sense?}

Quassim Cassam observes that "anti-Semitism is the original sin of Conspiracy Theories," and it comes as no surprise that antisemitism, that sturdy stalwart, continues to defy common sense today. ${ }^{8}$ It defies common sense when a "progressive" Washington, D.C. city council member posted a video blaming a snow storm on weather manipulation by the Rothschilds. ${ }^{9}$ It defies common sense when Europeans wildly overestimate the Jewish populations of their own countries even though most say they are unaware of ever having met a Jew. ${ }^{10}$ Holocaust agnosticism and ignorance are

spread by the government for nefarious purposes (9\%); and the mandated switch to compact fluorescent lightbulbs is a government mind-control plot (11\%). The percentages here are the sum of those who answered "agree" and those who answered "strongly agree." 6 Civiqs, "QAnon Support: Registered Voters," Sept. 10, 2020-Oct. 11, 2020, https://civiqs.com/results/qanon support?uncertainty=true\&annotations=true\&zoomIn=tr

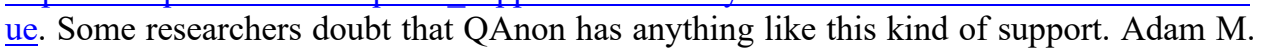
Enders \& Joseph E. Uscinski, "Is QAnon taking over America? Not so fast," The Guardian, August 18, 2020, https:/www.theguardian.com/commentisfree/2020/aug/18/qanonamerica-conspiracy-theory. Possibly QAnon followers are highly motivated by politics, so that they are overrepresented among the registered voters Civiqs surveyed.

${ }^{7}$ Katrin Bennhold, "QAnon Is Thriving in Germany; The Extreme Right Is Delighted," New York Times, $\quad$ Oct. $\quad 11, \quad 2020$, https://www.nytimes.com/2020/10/11/world/europe/qanon-is-thriving-in-germany-theextreme-right-is-delighted.html.

${ }^{8}$ Quassim Cassam, Conspiracy Theories (Polity Press, 2019), 123.

9 Peter Jamison \& Valerie Strauss, "D.C. lawmaker says recent snowfall caused by 'Rothschilds controlling the climate'," Washington Post, March 18, 2018. This particular opinion seems to originate with an internet conspiracy theorist who also maintains that wireless electric meters are part of a "diabolical" plot of global domination. Googling her name produced more than seven million results.

${ }^{10} \mathrm{CNN}$ polled in Austria, France, Germany, Hungary, Poland, Sweden, and Great Britain. A quarter of Hungarians, and one out of five Poles and British, believe that the world is more than $20 \%$ Jewish, a number off by a factor of 100 . "Four out of ten respondents in the survey thought their own countries were between $3 \%$ and $10 \%$ Jewish," where in fact no country other than Israel is more than $2 \%$ Jewish. Richard Allen Green, "CNN poll 
worldwide, and sadly come as no surprise. Given the passage of time, and abysmal ignorance of history across all topics, these are not necessarily departures from common sense. ${ }^{11}$ What defies common sense is that eleven percent of young Americans believe that the Jews caused the Holocaust. ${ }^{12}$

None of this would have surprised Hannah Arendt. The loss of common sense is one of the main themes of The Origins of Totalitarianism, where the phrase appears more than forty times; the very first page warns that "never have we depended so much on political forces that cannot be trusted to follow the rules of common sense." 13 In her later writings on moral judgment, Arendt returns repeatedly to questions about common sense and its collapse.

The questions are central to an inquiry into moral judgment. The connection between common sense and good judgment may seem obvious; indeed, some dictionaries define common sense as a species of good judgment ("sound and prudent judgment based on a simple perception of the situation or facts"; "sound practical judgment that is independent of specialized knowledge, training, or the like." ${ }^{14}$ ) However, we must not read these definitions to be saying that common sense judgment is, by definition, correct judgment. It needn't be. This is obvious in science and medicine, where common sense frequently turns out to be wrong; but it's also obvious in every human endeavor where judgment must be honed by training and experience to produce reliable results. Common sense by itself is no guarantor of truth or reliability.

Even apart from fields where judgment needs to be trained, we sometimes find ourselves confronted by hard choices in everyday life, in which two people of equal common sense might choose differently; that's what makes these choices hard. And we rightly recognize that some people are better at tough choices than others.

In sum, common sense doesn't guarantee good judgment. What nevertheless seems indisputable is that coming unhinged from common sense guarantees bad judgment. That is, although common sense isn't a

reveals depth of anti-Semitism in Europe," CNN, Nov. 2018, https://edition.cnn.com/interactive/2018/11/europe/antisemitism-poll-2018-intl/.

${ }^{11}$ After all, a third of surveyed Americans don't know in which century the American Revolution took place, and half believe it came after the Civil War, War of 1812, or the Emancipation Proclamation. Allen C. Brownfield, "The danger ignorance of history poses to a free society," American Council of Trustees and Alumni, April 22, 2018, https://www.goacta.org/news-item/the-danger-ignorance-of-history-poses-to-the-futureof-a-free-society/.

12 "Nearly two-thirds of US young adults unaware $6 \mathrm{~m}$ Jews killed in the Holocaust," The Guardian, Sept. 16, 2020, https://www.theguardian.com/world/2020/sep/16/holocaust-usadults-study. These numbers are not out of line with other countries.

${ }^{13}$ OT, vii.

${ }^{14}$ Merriam-Webster Dictionary on-line; Dictionary.com. 
sufficient condition for sound judgment, it is a minimum necessary condition.

Arendt tackles questions about common sense and its collapse from different angles in Origins, The Human Condition, the moral philosophy essays of the 1960s, and her final, incomplete book, The Life of the Mind. In Origins, the loss of common sense is rooted in social disintegration and isolation, resulting in cynicism and a reckless indifference toward factual truth that made millions of people patsies for totalitarian propaganda. The Human Condition ties the loss of common sense to excessive regard for subjective experience at the expense of the world we inhabit in common, an outlook she traces to Cartesian doubt and developments in the Scientific Revolution. In "Personal Responsibility Under Dictatorship" and "Some Questions of Moral Philosophy," she focuses specifically on the collapse of moral common sense, epitomized by Germany's frictionless slide from moral decency into crackpot racism and its murderous consequences. And in her final writings, she draws on Kant, who connected the cultivation of judgment with the formation of a critical judging community of common sense.

This paper examines Origins on the collapse of common sense, and its connection with propaganda. It keeps contemporary events very much in mind.

Before proceeding, I want to flag up front one of my conclusions in the paper: that what looks like a collapse of moral common sense may not be the mysterious inversion of values it seems. If a person has the outlandish factual belief that innocuous people are actually mortal enemies who pose a deadly threat, they may try to kill the imaginary enemies - not because they now think murder is virtuous, but because killing in self-defense is not murder. The apparent collapse of moral common sense can often be traced to a collapse of factual common sense.

\section{§2. Conspiracy Theories, Ideology, and Common Sense in The Origins of Totalitarianism}

Origins focuses on Nazi and Bolshevik totalitarianism and their precursors, but many of Arendt's observations have a resonance today that verges on the uncanny - a crucial reason to examine them closely.

The first chapter of Origins bears the title "Antisemitism as an Outrage Against Common Sense," and it poses its questions straightforwardly. How could the European Jews, a small, unarmed, politically unrepresented, largely self-secluded minority people, come to be feared and blamed for all the misfortunes in Christendom? How could the peoples of supposedly "modern" Europe come to believe the most incredible conspiracy theories about Jews? How could crackpot racial 
theories migrate from the fringe of society to the center of a mass murder project of unprecedented scale? All of it defies common sense.

To Arendt, an equivalent outrage to common sense was the "artificially fabricated insanity" of Stalin's USSR, where "one mysterious world conspiracy has followed another in Bolshevik propaganda, starting with the plot of the Trotskyites, followed by the rule of the 300 families, to the sinister imperialist (i.e. global) machinations of the British or American Secret Services" - to which she later added the antisemitic Doctors' Plot that the Kremlin unspooled between editions of Origins. ${ }^{15}$ The Moscow trials and executions of the Old Bolsheviks, based on their own confessions, are a prime instance of outrages against common sense.

If, for instance, all the "confessions" of political opponents in the Soviet Union are phrased in the same language and admit the same motives, the consistency-hungry masses will accept the fiction as supreme proof of their truthfulness, whereas common sense tells us that it is precisely their consistency which is out of this world and proves they are a fabrication. ${ }^{16}$

Here we see one of several political and psychological explanations Arendt offers for the loss of common sense: hunger for a consistent explanation that makes sense of the "fortuitousness that pervades reality," especially injustices (real or perceived), personal calamities, and mass misfortunes like economic crashes. ${ }^{17}$ Ideology supplies that need with what psychologists today call a monological belief system - "a unitary, closedoff worldview in which beliefs come together in a mutually supportive network." 18 Arendt uses the word "supersense."19 Such hyper-logical theories of everything are, automatically, more intellectually and

15 OT, 353 (artificially fabricated insanity), 351 (conspiracies), 351 n. 29, (conspiracy accusations against "Jewish cosmopolitanism"), xxxviii (Doctor's Plot).

${ }^{16} \mathrm{OT}, 352$.

${ }^{17}$ OT, 351-52.

${ }^{18}$ Michael J. Wood, Karen M. Douglas, and Robbie M. Sutton, "Dead and Alive: Beliefs in Contradictory Conspiracy Theories," Social Psychological and Personality Science 3(6) (2012): 767. The term comes from Ben Goertzel, Chaotic Logic: Language, Thought, and Reality from the Perspective of Complex Systems Science (Plenum, 1994) and Ted Goertzel, "Belief in Conspiracy Theories," Political Psychology 15(4) (1994): 740. Both Goertzels define a monological belief system as one that speaks only to itself, a description very much in harmony with Arendt's views about thinking and dialogue. Ben Goertzel elaborates that such a belief system is relatively immune to testing because it offers the identical master explanation for all events. In a dialogical belief system, by contrast, the structure of explanations will differ among different events, and each explanation will be relevant to the character of the event to be explained. PDF version of Chaotic Logic, 166.

${ }^{19}$ OT, 457-58. 
emotionally satisfying than the "fortuitousness that pervades reality," more commonly known as "shit happens.",

Even those who know better can be locked into the logical dungeon of supersense. In Arthur Koestler's Darkness at Noon, Rubashov (a fictionalized Bukharin) confesses to unreal crimes because the logic of Bolshevik ideology compels him to confess. That's an explanation not so far from Arendt's. We now know that many victims of the Great Terror confessed not because of "supersense" but because they were tortured; but others who were not tortured do seem to have confessed for Rubashovian reasons. As historian Yuri Slezkine explains the logic,

When it came to crimes against the Party, which stood for the Eternal Law, thoughts were not radically different from words, and words were not radically different from deeds. And when it came to the Party's Inquisition, sins were not radically different from crimes. ${ }^{21}$

Hence the confessions from men whose sole sin was having at some point doubted the wisdom of the Party line. Common sense tells us that is no reason to confess to crimes one hasn't committed. But common sense is precisely what ideology displaced.

Conspiracy theories, like ideologies, partake of supersense - and, as Arendt notes, they also resemble the mental constructions of paranoiacs, where everything follows inexorably from a delusional first premise; she adds that the insanity lies not only in the premise but also in the sheer logicality by which every observable fact snaps crisply into place within the theory. ${ }^{22}$ Reality is never that logical; it is untidy. Shit happens.

Some might protest that far from being hyper-logical, conspiracy theorists are supremely illogical. Survey subjects who believe Princess Diana is still alive are more likely than average to believe she was murdered. Likewise, people who believe that Osama bin Laden was already dead at the time of his killing are more likely to believe he is still alive. ${ }^{23}$ Cassam (understandably) concludes that these people hold contradictory views. ${ }^{24}$ That's not quite what the study shows, though. It finds that assent to the inconsistent theories rises and falls together; but that can easily be because subjects hold them in the alternative, not the conjunctive, and believe both are better than the Official Story. There is nothing illogical in thinking that

${ }^{20}$ See Pete Mandik, "Shit Happens," Episteme: The Journal of Social Epistemology 4 (2007): 205-18; Cassam, Conspiracy Theories, 26, 60 (on the unwillingness of conspiracists to accept that sometimes shit happens).

${ }^{21}$ Yuri Slezkine, The House of Government: A Saga of the Russian Revolution (Princeton University Press, 2017), 840-53; the quoted passage is at 844.

${ }^{22}$ OT, 457-58.

${ }^{23}$ Wood, Douglas \& Sutton, "Dead and Alive."

${ }^{24}$ Cassam, Conspiracy Theories, 45; Cassam, Vices of the Mind: From the Intellectual to the Political (Oxford UP, 2019), 70 n. 28. 
both of two inconsistent theories are more likely than a "known" falsehood. Where supersense comes in is the network of runaway inferences "proving" that the Official Story must be a lie.

Leaders were by no means immune to supersense. Stalin's ideology proclaimed that collectivized farms would be a socialist triumph. Instead, grain production in the Ukraine fell between 1931 and 1932. Since the Party line is infallible (premise), what could explain the failure? Stalin concluded it was intentional sabotage by counterrevolutionary and nationalist peasants. ${ }^{25}$ What else could it be? Sabotage calls for ruthless repression, not realistic grain quotas. To meet impossible and punitive quotas, even peasants' seed corn was confiscated, guaranteeing lower outputs at next planting. And that provided further proof of active sabotage. ${ }^{26}$

The result: millions starved to death in the Holodomor, Stalin's man-made famine in the Ukraine. Stalin never personally observed the mass starvation, but local officials did. "Forced to interpret distended bellies as political opposition, they produced the utterly tortured conclusion that the saboteurs hated socialism so much that they intentionally let their families die." ${ }^{27}$ Utterly tortured, utterly contrary to common sense - and utterly logical, given the axiom that the Party line can never be wrong.

\section{§3. Moral Common Sense}

A crucial point: Loss of common sense about factual reality leads to loss of common sense in moral matters. If Ukrainian peasants are starving their own families to death to sabotage socialism, perhaps they deserve to die. If the Jews are a powerful alien race locked in a death struggle with the German Volk, mass murder is self-defense. ${ }^{28}$ Mass murders are morally heroic if SS men kill for racial reasons and not for personal gain or gratification. ${ }^{29}$ If "my Trotskyite vacillations in 1923" led a Soviet official to attend dinners where the Party line was questioned, "I am profoundly guilty" of "counterrevolutionary wrecking activities" for failing to report the dinners to the secret police. ${ }^{30}$

${ }^{25}$ Timothy Snyder, Bloodlands: Europe Between Hitler and Stalin (Basic Books, 2010), $40-41,44$.

${ }^{26}$ Ibid., 45.

27 Ibid., 41.

28 Michael Wildt, "Eichmann und der kategorische Imperativ, oder: Gibt es eine nationalsozialistische Moral?" in Norbert Kampe and Peter Klein, eds., Die WannseeKonferenz am 20. Januar 1942: Dokumente, Forschungsstand, Kontroversen (Böhlau Verlag, 2013), 157-61.

${ }^{29}$ Ibid., 163-66. This comes from Heinrich Himmler's bone-chilling speech to the SS in Posen on October 4, 1943, discussed as well by Arendt, EJ 105-06.

${ }^{30}$ Slezkine, 843-44. The quotes are from Aron Gaister's confession. Gaister was a good Party man; at the time of the Holodomor, he praised the success of collectivized agriculture and celebrated "the liquidation of the contradiction between town and village." Ibid., 309. His confession was not extracted through torture, and he begged for a chance to expiate his thought crimes, which he freely admitted were dire. He was shot in 1937. 
It follows that crime is not crime, famine is justice, doubts are treason, racism is virtue, and the shining hallmark of the SS killer is his decency (Anstand). ${ }^{31}$ Here we see artificially fabricated moral insanity, in which common sense principles are twisted into moral hallucinations. Importantly, these examples don't require a total inversion of values, in which evil is now declared to be good. Self-defense, just punishment, patriotism, solidarity, and doing one's painful duty all belong to common sense morality. All they need to transform into moral insanity is the halftwist of applying them to factual claims that defy common sense. In Bolshevism and Nazism, the other half-twist was supplied by one genuine transvaluation of values: wholly subsuming the worth of individuals into the worth of the collective (the Volk or the class) and defining the sole moral imperative as victory over the collective's enemies.

\section{§4. Conspiracy Theories, Ideology, and Supersense}

Arendt discusses conspiracy theories, ideology, and totalitarian propaganda together. But it is important to recognize that conspiracy theories and ideologies are by no means the same thing. An ideology is a global worldview that purports to explain events as surface manifestations of larger forces, explicable by a few fundamental principles - for the Nazis, a biological struggle for existence among races, for the Bolsheviks, inexorable historical laws of class conflict. ${ }^{32}$ The ideologies Arendt focused on drew inspiration from the large-scale philosophies of history of the $19^{\text {th }}$ century, which conceptualized history not as a narrative of events, but as an unfolding process, governed by hidden laws of motion that it is the job of historians to uncover. ${ }^{33}$ Ideology of this sort connects the seeminglyrandom dots of histoire des événements into a lawlike pattern. In this respect, it sounds like science, and it has the pretension of being science, or at any rate of resting on science. The crucial difference is that where the aims of science are explanatory, ideologies are politicized through and through.

Conspiracy theories, by contrast, have little or nothing to do with science. In place of impersonal, law-governed forces of history, they substitute evil cabals executing secret plots. Conspiracy theories and ideologies both try to make sense (or supersense) of events as surface manifestations of hidden realities, and both are political; but there the

\footnotetext{
${ }^{31}$ Wildt, 163-66. Again, this comes from Himmler's 1943 Posen speech.

32 These, Arendt notes, are the two ideologies that "have come out on top and essentially defeated all others." OT, 159. She did not mention, and probably never studied, the laissezfaire Social Darwinism of the US and Britain at the turn of the $20^{\text {th }}$ century, which persists in some libertarian circles today. But this too qualifies as a dominant ideology.

33 Arendt, "The Concept of History," in Between Past and Future: Eight Exercises in Political Thought (New York: Viking, 1968). I analyze this essay in Luban, "Hannah Arendt's Theory of Theory," Social Research 50(1) (1983): 215-48, revised and reprinted under title "Hannah Arendt and the Primacy of Narrative," in Luban, Legal Modernism. The obvious progenitor was Hegel; see OR, 45-49.
} 
resemblance stops. Many of today's conspiracy theorists are frankly antiscience, because scientists belong to the shadowy elites that conspiracy theorists hate and fear. ${ }^{34}$ These conspiracists may appear to be credulous, and in obvious ways they are. Yet, as Brian Keeley observes, they also have an almost nihilistic level of skepticism about anything the authorities say, including scientific authorities and experts. ${ }^{35}$

In that respect, today's New Conspiracists are close cousins to flatEarthers, whose ranks are apparently swelling courtesy of the internet and social media. ${ }^{36}$ Part of the challenge facing flat-Earthers is explaining why their opinions are widely scorned; and the natural answer is that the scientists must be in on the plot to hide the truth, in cahoots with the media and - inevitably - the government. Imagine the vast scientific betrayals that went into faking those space station photos of Round Earth, not to mention the perfidious cartographers who flood the world with globes showing Antarctica rather than the wall of ice that holds the oceans in! - What looks at first glance like a harmless dotty view about an apolitical natural fact turns out to be deeply political; in the words of a psychologist who studies the flat-Earth subculture, they "view the world through this really dark filter where [they] assume that all authorities and institutions and corporations are just there to exploit you." 37

The sheer contingency of facts means that facts could have been otherwise. ${ }^{38}$ That opens a logical space for conspiracy theories: they could be true. Because the conspiracy theory could be true, the burden of proof is on you to show it isn't, or so the conspiracist insists. You can't deny that sinister and incredible government conspiracies actually have existed consider, for example, the CIA's multi-year, multi-million-dollar secret research into mind control, which included dosing unwitting subjects with

\footnotetext{
${ }^{34}$ On the related point that the "new conspiracism" is conspiracy shorn of political theory, see Russell Muirhead and Nancy L. Rosenblum, A Lot of People Are Saying: The New Conspiracism and the Assault on Democracy (Princeton UP, 2019), ch. 1.

${ }^{35}$ Brian L. Keeley, "Of Conspiracy Theories,” Journal of Philosophy 96(3) (1999): 125 26.

${ }^{36}$ Rob Picheta, "The flat-Earth conspiracy is spreading around the globe. Does it hide a darker core?", CNN, Nov. 18, 2019, https://www.cnn.com/2019/11/16/us/flat-earthconference-conspiracy-theories-scli-intl/index.html. More than a quarter of Americans believe the Sun goes around the Earth. National Science Board, Science and Engineering Indicators 2018, https://www.nsf.gov/statistics/2018/nsb20181/report/sections/scienceand-technology-public-attitudes-and-understanding/public-knowledge-about-s-t. I take the label "New Conspiracism" from Muirhead and Rosenblum.

37 Rachel Brazil, "Fighting flat-Earth theory," Physics World, July 14, 2020, https://physicsworld.com/a/fighting-flat-earth-theory/, quoting psychologist Asheley Landrum.

${ }^{38}$ This is a point Arendt emphasizes in "Truth and Politics," in Between Past and Future, 242: "facts have no conclusive reason whatever for being what they are; they could always have been otherwise, and this annoying contingency is literally unlimited."
} 
LSD. ${ }^{39}$ If it could happen then, the conspiracist reasons, why doubt that it is happening now? Invariably, the conspiracist has boatloads of "evidence." Unless you're willing to waste your life fact-checking the rubbish heap of minutiae that conspiracists always have at their fingertips, the conspiracists triumph, at least in their own minds. ${ }^{40}$

If conspiracy theories are anti-science, what is their connection with "scientific" totalitarian ideologies? The answer is that conspiracy theories can get along fine without a scientific ideology - as shown by the antiscience "new conspiracism" - but a scientific ideology, which (in Arendt's words) "pretends to have found the key to history or the solution to the riddles of the universe," needs conspiracy theories. ${ }^{41}$

First, as Stalin's devastating diagnosis of the bad Ukrainian harvest illustrates, conspiracy theories are necessary to explain away the inevitable but embarrassing predictive failures of the ideology. Events would have unfolded as the ideology predicted (so the supersense reasoning goes) if it hadn't been for sabotage - which, by the way, the ideology rightly anticipated. Conspiracy theories provide convenient, easy-to-understand auxiliary hypotheses patched on to a theory to make it fit errant data. As a historian of Soviet Russia notes:

For at least a decade Bolshevik authorities had promoted the idea that there were no accidents in the Soviet Union, no

\footnotetext{
39 The program, code-named MK-ULTRA, came to light during several congressional investigations in the 1970s. See Stephen Kinzer, Poisoner in Chief: Sidney Gottlieb and the CIA Search for Mind Control (New York: Henry Holt, 2019); Alfred McCoy, A Question of Torture: CIA Interrogation from the Cold War to the War on Terror (Holt, 2006). Congressional investigations: Report to the President by the Commission on CIA Activities Within the United States (June 1975); Joint Hearings on Biomedical and Behavioral Research before the Subcommittee on Health of the Senate Committee on Labor and Public Welfare and the Subcommittee on Administrative Practice and Procedure of the Senate Judiciary Committee (1975); Project MKUltra, the CIA's Program of Research in Behavioral Modification: Joint Hearing Before the Select Comm. on Intelligence and the Subcomm. on Health and Sci. Res. of the Comm. on Hum. Ress., 95th Cong. 62 (1977); Human Drug Testing by the CIA, United States Senate Subcommittee on Health and Scientific Research and the Committee on Human Resources, on S. 1893, to Amend the Public Health Service Act to Establish the President's Commission for the Protection of Human Subjects of Biomedical and Behavioral Research, and for Other Purposes (1977), http://www.gulfwarvets.com/HumanDrug.pdf; Cold War Era Human Subject Experimentation: Hearing Before the Legislation and National Security Subcomm. of the H. Comm. on Government Operations, 103rd Cong., (1994) https://perma.cc/T6MBQGJ5.

${ }^{40}$ Richard Hofstader's famous essay on the "paranoid style" in American politics notices the conspiracist's "almost touching concern with factuality" as he "carefully and all but obsessively accumulates "evidence" in order to "prove that the unbelievable is the only thing that can be believed." Hofstader, "The Paranoid Style in American Politics," Harper's Magazine, Nov. 1964, https://harpers.org/archive/1964/11/the-paranoid-style-inamerican-politics/. There is a great deal of overlap between Hofstader's essay and Arendt's observations.

${ }^{41}$ OT, 457.
} 
incompetence, no random crimes, no freak catastrophes. Industrial accidents, production below plan, theft, murder, and rape were "not coincidental." They all had political meanings; they were all perpetrated by saboteurs, class enemies, and foreign intelligence services. ${ }^{42}$

Conspiracy theories make great auxiliary hypotheses to save the ideology. For, as Keeley points out, to a conspiracist evidence against the theory is really evidence for it: it shows how desperate the conspirators are to bury the truth. Hitler wrote that proof that the Protocols of the Elders of Zion are a forgery is actually "the surest proof that they are genuine." 43

Second, and obviously, conspiracies justify crackdowns and repression, which totalitarian or strongman regimes ruthlessly exploit. An instructive illustration is Recep Tayyip Erdoğan's purge of supposed "Gulenist" conspirators in the wake of the 2016 Turkish coup attempt. The coup attempt was real, but it provided Erdoğan a welcome excuse for a purge of wider scope, sweeping away independent judges, liberal academics, and other regime critics whom Erdoğan had yearned for years to get rid of. Needless to say, many have no connection whatever with Gulen.

Third, to be translated from esoteric theory to user-friendly mass propaganda, ideologies need to be repackaged, dumbed down, and dramatized. In Arendt's words:

Bolshevism and Nazism began even to eliminate those sources of their own ideologies which had already won some recognition in academic or other official quarters. Not Marx's dialectical materialism, but the conspiracy of 300 families; not the pompous scientificality of Gobineau and Chamberlain, but the "Protocols of the Elders of Zion"; not the traceable influence of the Catholic Church and the role played by anti-clericalism in Latin countries, but the backstairs literature about the Jesuits and the Freemasons became the inspiration for the rewriters of history. The object ... was always to reveal official history as a joke, to demonstrate a sphere of secret influences of which the visible, traceable, and known historical reality was only the outward façade erected explicitly to fool the people. ${ }^{44}$

There is no contradiction between "low" conspiracy theory and "high" ideology, because conspiracy theories can run comfortably in parallel with

42 Matt Lenoe, "Did Stalin Kill Kirov and Does It Matter?" Journal of Modern History 74(2) (2002): 352.

${ }^{43}$ Keeley, 120. Hitler quoted from Mein Kampf in Richard J. Evans, The Hitler Conspiracies (Oxford University Press, 2020), 32.

${ }^{44}$ OT, 333. 
the more abstract, academic, and "respectable" ideologies to form a unified propaganda package that appeals to elites and masses alike.

Ludwig Bieberbach, a University of Berlin math professor and ardent Nazi, could publish a "scientific" book about the influence of blood and race on mathematical styles. (After trying and failing to find decent excuses for Bieberbach's theories, a renowned British mathematician commented that he found himself "driven to the more uncharitable conclusion that he really believes them true." ${ }^{45}$ ) Dr. Mengele's mentor Otmar von Verschuer ran a well-funded anthropology, genetics, and race science institute; he lectured to London's Royal Society on twin research (Mengele's specialty at Auschwitz) as late as three months before the war. ${ }^{46}$ Meanwhile, street-level racists with no interest in genetics or the difference between "J-type" and "S-type" mathematics could settle for the Protocols of the Elders of Zion.

\section{§5. Arendt's political sociology in Origins}

What explains contempt for the rules of common sense? Origins offers several explanations, historical, psychological, and philosophical. My interest is mostly philosophical, but a quick overview of Arendt's historical and psychological diagnoses will provide useful context.

We have already seen one such diagnosis: Arendt roots the loss of common sense in the human need for meaningful explanations, however farfetched, of manmade disasters and injustices that befall us. Trying to make sense of economic crashes and the incomprehensibly pointless carnage of the First World War drove many Europeans to supersense at the expense of common sense. But that raises a question: why now? After all, misfortune and injustice are always with us, and so is the human need to make sense of calamities.

Arendt's answer, in brief, is that nineteenth century capitalism's production of "superfluous wealth and superfluous men" shredded the traditional European class system and created a mass society of atomized individuals, who no longer understood their place in the world, and were therefore ripe for recruitment into mass movements peddling meaning in the form of supersense. ${ }^{47}$ Politically, parliamentary democracy - with its give and take of opinions rooted in real interests - depended on a system in

${ }^{45}$ G. H. Hardy, Collected Papers, vol. 7, 611, quoted in Robert Kanigel, The Man Who Knew Infinity: A Life of the Genius Ramanujan (Charles Scribner, 1991), 366. Bieberbach's book is Stilarten mathematischen Schaffens [Styles of Mathematical Creativity] (Akademie der Wissenschaften, 1934). In a historical irony, the mathematical conjecture bearing Bieberbach's name was finally proven by a Hitler refugee; Bieberbach's Conjecture is now de Brange's Theorem.

${ }^{46}$ David G. Marwell, Mengele: Unmasking the Angel of Death (Norton, 2020), 90; Otmar von Verschuer, "Twin Research from the Time of Galton to the Present Day," Proceedings of the Royal Society of London, Series B Biological Sciences 128 (1939): 62-81.

${ }^{47}$ OT, 200, 225. The word "superfluous" is one of Arendt's favorites, appearing more than ninety times in OT, usually in the context described here. 
which parties represented classes; with the "wreckage of classes" 48 the party system collapsed and the mass movement prevailed.

Let's take a deeper look. Arendt's detailed analysis employs a political sociology of her own device, a quirky taxonomy of European society in the late nineteenth and early twentieth centuries built around six categories: the mob, the people, the masses, the bourgeoisie, the philistines, and the elites.

\section{The mob and the people}

The mob corresponds roughly with Marx's lumpenproletariat, an underclass of the angry, disaffected, thwarted, cynical, and violent - with one significant difference. For Arendt, the mob is drawn from all classes, because she includes in it the inciters and abettors of mob violence, not just the perpetrators. She introduces the term in her discussion of France's Dreyfus affair, where tangible, physical mobs were egged on by the military and antisemitic intellectuals. Quoting blood-curdling antisemitic rhetoric from the supposedly respectable classes, she remarks, "While the mob actually stormed Jewish shops and assailed Jews in the streets, the language of high society made real, passionate violence look like harmless child's play." She adds: "The upper classes knew that the mob was flesh of their flesh and blood of their blood."49

For Arendt, the mob need not be a literal mob, and the AntiDreyfusard mob is only an instance of "the human debris that every crisis, following invariably upon each period of industrial growth, eliminated permanently from producing society", 50 it is "the refuse of all classes" 51 from whose ranks, among other things, were drawn the adventurers and soldiers of fortune in Europe's African imperialism, along with the underworld. Today, we might well include in the mob actual physical mobs and armed groups, but also armies of internet trolls with their distinctive brand of nihilism and self-loathing, channeled into universal otherloathing. ${ }^{52}$

Because the mob (in her expanded sense) is drawn from all classes, it can easily be mistaken for the people, "which also comprises all strata of society. While the people in all great revolutions fight for true representation, the mob always will shout for the 'strong man,' the 'great leader.' For the mob hates society from which it is excluded." 53 Arendt's scattered comments on the mob resonate strongly with contemporary

${ }^{48}$ OT, 326

${ }^{49} \mathrm{OT}, 107$

${ }^{50} \mathrm{OT}, 150$

${ }^{51} \mathrm{OT}, 155$.

${ }^{52}$ See Hari Kunzru, "For the Lulz" (reviewing Dale Beran, It Came from Something Awful: How a Toxic Troll Army Accidentally Memed Donald Trump Into Office), New York Review of Books 67(5), March 26, 2020: 4-8.

${ }^{53} \mathrm{OT}, 107$. 
analyses of populism, where strong-man leaders appeal to the mob by assuring them that they alone are the true people, and any political opponents are enemies of the people. ${ }^{54}$

\section{Masses and philistines}

The masses are different from the mob, although Arendt cautions that once totalitarian movements acquired mass followings it was easy to overlook the difference, because the mentality of their leaders so closely resembled that of nineteenth-century mob leaders. ${ }^{55}$ Arendt defines "masses" as follows:

The term masses applies only where we deal with people who either because of sheer numbers, or indifference, or a combination of both, cannot be integrated into any organization based on common interest, into political parties or municipal governments or professional organizations or trade unions. Potentially, they exist in every country and form the majority of those large numbers of neutral, politically indifferent people who never join a party and hardly ever go to the polls. ${ }^{56}$

Her key conclusion is that totalitarian movements arise "wherever there are masses who for one reason or another have acquired the appetite for political organization." 57 The psychology of the masses includes "a typical feeling of superfluousness - ... the concomitant of mass unemployment and the population growth of the last 150 years," manifesting itself psychologically, or one might even say spiritually, in "self-centered bitterness." 58

Included among the masses are what she calls the philistines - "the bourgeois isolated from his own class, the atomized individual who is produced by the breakdown of the bourgeois class itself." ${ }^{59}$ Here she evidently means the downwardly-mobile middle classes in times of economic and social crisis.

The mass man whom Himmler organized for the greatest mass crimes in history bore the features of the philistine rather than the mob man, and was the bourgeois who in the midst of the ruins of his world worried about nothing so much as his private security, was ready to sacrifice

\footnotetext{
54 Jens Werner-Müller, What Is Populism? (Penguin, 2015).

${ }^{55}$ OT, 313-4.

${ }^{56} \mathrm{OT}, 311$.

57 OT, 311 .

${ }^{58}$ OT, 311 (superfluousness), 315 (bitterness).

${ }^{59}$ OT, 338.
} 
everything - belief, honor, dignity - on the slightest provocation. ${ }^{60}$

\section{The bourgeoisie}

Elsewhere in Origins where she speaks of the bourgeoisie, Arendt means capitalists, that is, owners of capital, not the middle classes. Arendt accepts Marx's insight that what makes capitalism distinctive is not acquisitiveness but endless expansion of capital, "the bourgeoisie's empty desire to have money beget money," in which "wealth became a neverending process of getting wealthier." 61 To this she adds Rosa Luxemburg's insight that this process will require endless expansion and therefore imperialism - which, in Arendt's analysis, contradicts the nation-state principle and presaged the $20^{\text {th }}$ century collapse of the system of European nation-states. $^{62}$

Most conspicuously, she draws her picture of the (big) bourgeoisie from a reading of Hobbes - "the true ... philosopher of the bourgeoisie" and "the only great thinker who ever attempted to derive public good from private interest." ${ }^{3}$ Hobbes reduces reason to "Reckoning," and human worth to whatever price the market fetches for one's labor power. Accordingly, the bourgeois state is grounded in self-interest, not law or right. And "[p]ower, according to Hobbes, is the accumulated control that permits the individual to fix prices and regulate supply and demand in such a way that they contribute to his own advantage. ... Therefore, ... desire for power must be the fundamental passion of man." ${ }^{4}$ Hobbes is "the great idolator of Success." 65

I leave to one side the accuracy of Arendt's quirky Hobbes interpretation. For our purposes, what matters is not whether Arendt got Hobbes right (I doubt it), but what she thinks she gets from Hobbes, namely a picture of the bourgeois as a success-worshipping moral hypocrite. Her political critique is that the bourgeois willingness to sacrifice freedom for prosperity and security rests on the fallacy that public good can come from aggregating private interests. ${ }^{66}$

But hers is also a moral critique, and as Arendt explores the political psychology that gave rise to totalitarian movements, the moral critique takes on a central role. For, at the same time the bourgeoisie wrests power from

${ }^{60} \mathrm{OT}, 338$.

${ }^{61} \mathrm{OT}, 137,145$.

${ }^{62}$ OT, 148 (citing Luxemburg's The Accumulation of Capital). On the contradiction between the nation-state principle and imperial expansion, see OT, 124-28; on the inner contradiction of the nation-state principle, OT, 229-36; on the breakdown of the parliamentary party system, OT, 252-66.

${ }^{63}$ OT, 139, 146.

${ }^{64} \mathrm{OT}, 139$.

${ }^{65}$ OT, 144, 146.

${ }^{66}$ OT, 145-46; 336. 
the aristocracy, it embraces the fiction of its own invincible rectitude, namely the fiction that its moral rules aim solely to protect the innocent pursuit of private interest. Bourgeois morality is a hypocritical overlay of pieties masking something far uglier and more ruthless.

\section{The elites}

The unmasking of bourgeois hypocrisy came from the elites. One of Arendt's themes is the alliance between elites and the mob, evinced early on in "high society's constantly growing admiration for the underworld, which runs like a red thread through the nineteenth century, its continuous step-by-step retreat on all questions of morality, and its growing taste for the anarchical cynicism of its offspring. ${ }^{" 67}$ Elite cynicism intensified after the cataclysm of World War I. The war's trauma filled the Lost Generation (Arendt calls it the "front generation") with a bitter, brittle nihilism. Today, we might diagnose the syndrome as moral injury, a cousin to PTSD. ${ }^{68}$ As a contemporary psychiatrist observed, the mantras his Vietnam veteran patients used to shrug off their pain and loss - "Don't mean nothing" and "Fuck it!" - eventually "spread out to engulf everything valued or wanted, every person, loyalty, and commitment." 69

The disillusioned, morally injured front generation included not only the demobilized soldiers, but also civilian contemporaries who shared their bitterness and "were completely absorbed by the desire to see the ruin of this whole world of fake security, fake culture, and fake life."70 They were filled with "justified disgust" for the pieties of bourgeois morality. Among literary elites this disgust manifested itself in "their brilliant and witty praise of violence, power, and cruelty." "71 The mob wanted "access to history even at the price of destruction" - and the elites who egged them on "did not object at all to paying a price, the destruction of civilization for the fun of seeing how those who had been excluded unjustly in the past forced their way into it." 72 They did it for the lulz.

\footnotetext{
${ }^{67} \mathrm{OT}, 155$.

${ }^{68}$ Moral injury among soldiers comes from "perpetrating, failing to prevent, bearing witness to, or learning about acts that transgress deeply held moral beliefs and expectations." Brett T. Litz et al., "Moral injury and moral repair in war veterans: A preliminary model and intervention strategy," Clinical Psychology Review 29 (2009): 700. Classics in the literature on military moral injury are Jonathan Shay, Achilles in Vietnam: Combat Trauma and the Undoing of Character (Simon \& Schuster, 1995); David Wood, What Have We Done? The Moral Injury of Our Longest Wars (Little Brown Spark, 2016); Nancy Sherman, Afterwar: Healing the Moral Wounds of Our Soldiers (Oxford University Press, 2015). Current data estimates that moral injury afflicts up to one in five veterans returning from U.S. wars in the Middle East.

${ }^{69}$ Shay, Achilles in Vietnam, 38. Arendt thought that the traumatic experiences of the front generation expressed themselves in "nihilistic banalities." OT, 442.

70 OT, 328.

${ }^{71}$ OT 328 (“justified disgust"), 330.

72 OT, 332.
} 


\section{The upshot}

What should we make of Arendt's taxonomy? It is not grounded in demographic data, surveys, or psychology experiments; rather it is a narrative cultural study. ${ }^{73}$ An obvious first question is whether her underlying history is reliable. The breadth of her research is remarkable. We should nevertheless expect errors of fact at the granular level - after all, Arendt had no access to Soviet archives, she did not read Russian, her material resources were meager, and there has been a mountain of research in the seven decades since Origins. (To cite just one example: based on news reports of Khrushchev's secret 1956 speech, Arendt accepted the popular theory that Stalin arranged the Kirov murder that he used as an excuse for the Great Purge. Subsequent historians, with access to Soviet archives, have mostly discredited it. ${ }^{74}$ ) For present purposes, there is no need to sort out this kind of thing, and in any case sorting it out isn't anything I am equipped to undertake.

As for the overarching narrative - the macro- rather than microhistory - subsequent decades have generated major disputes between competing interpretations of Nazi Germany and Stalinist Russia. Some are roughly consistent with Arendt, others decidedly not. ${ }^{75}$ There are likewise differing accounts of the class composition of the Nazi base. Again, some of these views are consistent with Arendt, others less so. ${ }^{76}$ A bigger problem

${ }^{73}$ I have argued that Arendt's "methodology" (if I may use that ugly word) lies at the heart of her understanding of how to write history in dark times. Luban, "Hannah Arendt's Theory of Theory."

${ }^{74}$ OT 390, note 3; Lenoe, "Did Stalin Kill Kirov and Does It Matter?" concludes that the story is false, but also points out that some reputable historians still disagree. Lenoe's instructive article shows how immensely complicated it is to ascertain the truth, even after the secret Soviet archives became available.

75 Thus, within Soviet studies, "revisionists" like J. Arch Getty dispute with "totalitarian" interpretations of Stalinist terror like that of Arendt and Robert Conquest; Third Reich and Holocaust historians long divided between "functionalists" and "intentionalists" (or a fusion: Richard Bessel, "Functionalists vs. Intentionalists: The Debate Twenty Years on or What Has Happened to Functionalism and Intentionalism?", German Studies Review 26(1) (2003): 15-20). Although they draw on a wealth of information unknown to Arendt, histories through the 1980s and '90s are not necessarily more reliable, because they are often colored by Cold War polemics and the complicated politics of remembrance, dramatically exemplified in the West German "Historians' Controversy" of the late 1980s and the Goldhagen Affair a decade later.

${ }^{76}$ See the useful literature review by Stephen G. Fritz, "The NSDAP as Volkspartei? A Look at the Social Basis of the Nazi Voter," The History Teacher 20 (1987): 379-99. Revisionists who question the received view that the NSDAP was a party of the middle classes point to surprisingly high support for the Nazis across classes in the 1932 election. Their argument is far from decisive, though, because voting behavior is an imperfect measure of belief or the grounds of support, and Arendt's categories don't map onto conventional economic and social classes; in any case, even the revisionists agree that the anxious middle classes were the primary Nazi constituency. Ibid., 379-80, 394-95. A leading revisionist, Richard Hamilton, has argued that both the lower-middle-class thesis and the mass society argument have been discredited, but it is far from clear that his version of the mass society argument is Arendt's - Hamilton appears to equate mass society with 
is that her picture of Nazi Germany and the Stalinist USSR is a composite, and some elements are true of one but not the other. Arendt is not careful to sort these out. But, as with the granular micro-history, for our purposes there is no need to enter the fray of competing historical interpretations of the macro-history. Whether or not Arendt was right about how Germany got to the point that millions of people lost their moral and factual common sense, the point is that they lost it.

Obviously, Arendt's categories are anything but a neutral descriptive sociology. Mob and philistines are words of contempt, just as the people is a theory-laden republican praise-word. Bourgeoisie can be used as a neutral class category, but Arendt leaves no doubt that she associates Europe's $19^{\text {th }}$ and early $20^{\text {th }}$ century bourgeoisie with moral rot. Masses, defined as people with no interest in public life, comes closest to a purely descriptive term; but Arendt gives it a largely negative inflection and warns that mass society is ripe for totalitarian recruitment. As for the elites, her disgust at their casual nihilism could hardly be plainer. Hers is a morally loaded, normative sociology, not a social science description. And Origins is as much a moral argument as a historical and political analysis.

Her sociology is specific to a unique epoch and place, as Arendt herself emphasizes. Readers will have no difficulty finding contemporary analogues to Arendt's categories. For example, Arendt attributes the "revolt of the masses against ... common sense" to "their loss of social status along with which they lost the whole sector of communal relationships in whose framework common sense makes sense." $" 77$ An entire literature about populism and polarization in the contemporary United States offers variants of the same diagnosis. But there are no one-to-one correspondences between then and now, and we should beware of superficial analogies, which come almost too easily. For present purposes, the leading question is not how Arendt's typology applies today, but rather what any of this has to do with the loss of common sense.

A great deal, as it turns out. The punchline of Arendt's story of class wreckage, atomization of masses, and backlash against hypocrisy is a corrosive attitude toward factual truth that she was among the first to pinpoint. In addition to the epigraphs to this paper, consider a few other observations:

urban society. Hamilton, "The Rise of Nazism: A Case Study and Review of Interpretations: Kiel, 1928-33," German Studies Review 26 (2003): 44-45, 58-59. Moreover, the composition of the base changed as the Nazis morphed from sect to party to movement to regime. Peter Baldwin identifies more than a dozen subgroups of Nazi supporters over the life of National Socialism, including several flavors each of believers, opportunists, and Johnny-come-latelys - all categories of which Arendt was acutely aware. Peter Baldwin, "Social Interpretations of Nazism: Renewing a Tradition," Journal of Contemporary History 25(1) (1990): 7.

77 OT, 352. 
Mass propaganda discovered that its audience was ready at all times to believe the worst, no matter how absurd, and did not particularly object to being deceived because it held every statement to be a lie anyhow.

A mixture of gullibility and cynicism is prevalent in all ranks of totalitarian movements, and the higher the rank the more cynicism weighs down gullibility. The essential conviction shared by all ranks, from fellow-traveler to leader, is that politics is a game of cheating. ${ }^{78}$

The difference between truth and falsehood may cease to be objective and become a mere matter of power and cleverness, of pressure and infinite repetition. ${ }^{79}$

The true goal of totalitarian propaganda is not persuasion but organization. $^{80}$

And this from "Truth and Politics," an essay written in 1967:

$[\mathrm{F}]$ actual truth is no more self-evident than opinion, and this may be among the reasons that opinion-holders find it relatively easy to discredit factual truth as just another opinion. ${ }^{81}$

In this environment, propagandists happily exploit the conviction that all opinions are created equal. Arendt's observations seem as recognizable, and as devastatingly valid, today as when Arendt wrote them seventy years ago. I was not surprised when a U.S. Marine general, an expert on information warfare, told me that he urges his colleagues and students to study the chapter on propaganda from The Origins of Totalitarianism.

\section{§. The epistemology of bullshit}

Let's focus on two of her observations - that mass propaganda's audience "was ready at all times to believe the worst, no matter how absurd, and did not particularly object to being deceived because it held every statement to be a lie anyhow," and that their mental state is therefore a "mixture of gullibility and cynicism." That mental state sounds like a contradiction in terms. Gullibility normally means excessive willingness to believe, while cynicism means something close to the opposite.

The solution to the contradiction it is to reframe gullibility as the willingness to accept anything, without necessarily taking it to be true, either because it comes from a favored partisan source, or because one has cynically devalued truth (or both). A perceptive journalist described the attitude of Donald Trump's followers to his torrent of lies as falling

\footnotetext{
${ }^{78} \mathrm{OT}, 382$.

${ }^{79} \mathrm{OT}, 333$.

${ }^{80} \mathrm{OT}, 361$.

81 "Truth and Politics," in Between Past and Future, 243.
} 
"somewhere between true belief and being in on the joke." lot like gullibility (true belief) and cynicism (being in on the joke). A clickbait entrepreneur who makes his living purveying fake news offers a related diagnosis: Trump "just said whatever he wanted, and people believed everything, and when the things he said turned out not to be true, people didn't care because they'd already accepted it." ${ }^{\prime 3}$

Muirhead and Rosenblum describe the gullibility side of this attitude as being willing to settle for "true enough" rather than "true" ("well, it may not be true, but it's true enough"), adding that the corresponding propositional attitude is neither belief nor disbelief. ${ }^{84}$ Conspiracists are willing to settle for "true enough," because whose views you accept and whose you reject has become a matter of tribal identity rather than factual belief. Here one thinks of Arendt's observation (quoted above) that the goal of propaganda is not persuasion but organization. Persuasion aims at changing someone's belief; organization aims at recruiting them to a tribe, so that belief and truth no longer matter. Or rather, the only truth that matters is truth about tribal identity. What matters isn't factual reality, but the reality of "us," the real people, in contrast to the poisonous subtlety of "them," the tribal adversary in the body politic.

\section{Epistemic malevolence}

Contemporary philosophers have become increasingly interested in epistemic vices - mental attitudes that conduce to falsehood, just as mental attitudes and traits like attentiveness and honesty conduce to truth. One such vice is epistemic malevolence, an oppositional attitude toward the truth, manifesting itself in active efforts to defeat truth and frustrate truthseekers. ${ }^{85}$ This may seem like just a fancy label for lying, but it is a broader category. Epistemic malevolence also includes information suppression (erasing or stealing public records; bribing, intimidating, or murdering

82 Mark Leibovich, “Trump Has Called His Supporters 'Disgusting.' Do They Care?," New York Times, October 10, 2020, https://www.nytimes.com/2020/10/10/sundayreview/trump-supporters.html?searchResultPosition=1. In the same vein, two years earlier, a professional fact-checker reported that many of the vitriolic emails he received from Trump's supporters say that they like Trump's lying "because it bothers 'elites' like me." Daniel Dale, "It's Easy to Fact-Check Trump's Lies. He Tell the Same Ones All the Time," Washington Post, Nov. 16, 2018, https://www.washingtonpost.com/outlook/its-easy-tofact-check-trumps-lies-he-tells-the-same-ones-all-the-time/2018/11/15/5effb25c-e87411e8-a939-9469f1166f9d story.html.

${ }^{83}$ Caitlin Dewey, "Facebook fake news writer: 'I think Donald Trump is in the White House because of me'," Washington Post, Nov. 17, 2016, https://www.washingtonpost.com/news/the-intersect/wp/2016/11/17/facebook-fakenews-writer-i-think-donald-trump-is-in-the-white-house-because-of-me/.

${ }^{84}$ Muirhead and Rosenblum, 43.

${ }^{85}$ The term comes from Jason Baehr, "Epistemic Malevolence," Metaphilosophy 41 (2010): 189-213, reprinted in Heather Battaly, ed., Virtue and Vice: Epistemic and Moral (Blackwell, 2010). Cassam's discussion of epistemic malevolence is very useful: Vices of the Mind, 88-92. 
witnesses; no-snitch honor codes like omertá and police forces' "blue wall of silence").

In addition, it includes what I will call epistemic decoy flooding, the release and circulation of so much fake news, sometimes commingled with truth, that it is nearly impossible to sort out truth and falsehood in real time. The analogy is to military tactics such as releasing decoy balloons with the same radar characteristics as missiles to confuse missile detection systems, or surrounding warships with a flotilla of civilian craft. Besides camouflaging the truth, Regina Rini shows that an especially deadly aim of epistemic decoy flooding is to make the truth seem to be merely one of several spin-doctored narratives. As Rini argues, it actually helps malign actors if some of their fake news is transparently false. "The point is not to implant false beliefs. Rather, the point is to induce skepticism. By flooding the channels of public discourse with falsehood, then allowing citizens to know that this has happened, anti-democrats make it reasonable for us to trust no one, least of all our co-citizens." ${ }^{\text {"6 }}$ Arendt anticipated Rini's observation when she wrote that "factual truth is no more self-evident than opinion, and this may be among the reasons that opinion-holders find it relatively easy to discredit factual truth as just another opinion." 87

Of course, suppression and concealment need not count as malevolence in a moral sense - that depends on whether keeping something secret is morally justified or not. Not everyone is entitled to know everything that everyone else knows. In a courtroom setting, suppression includes lawful tactics such as invoking the attorney-client privilege or fighting discovery. While legal suppression tactics can be abused, they also serve legitimate purposes. In such cases epistemic malevolence need not imply moral malevolence - but information suppression is, by definition, epistemically malevolent nonetheless.

An instructive example of epistemic and moral malevolence, using otherwise legitimate suppression tactics, is the tobacco industry's decadeslong effort to keep the public ignorant or at least doubtful about the harmful effects of smoking. ${ }^{88}$ The effort was meticulously orchestrated. To reassure

\footnotetext{
${ }^{86}$ Regina Rini, "Weaponized Skepticism: An analysis of social media deception as applied political epistemology," in Elizabeth Edenberg \& Michael Hannon, eds., Political Epistemology (Oxford University Press, forthcoming), manuscript pp. 3, 12.

87 "Truth and Politics," 243.

${ }^{88}$ This is Cassam's prime example of epistemic malevolence, although I focus on a different aspect of it than he does, namely the abuse of the attorney-client privilege. Cassam, Vices of the Mind, 89-91. See also Cailin O'Connor and James Owen Weatherall, The Misinformation Age: How False Beliefs Spread (Yale University Press, 2019), 93117 , an extended case study of how the tobacco strategy produced false scientific beliefs without actually lying about the science. Both books draw on Naomi Oreskes and Erik M. Conway, Merchants of Doubt: How a Handful of Scientists Obscured the Truth on Issues from Tobacco Smoke to Global Warming (Bloomsbury, 2010). On the tobacco industry's abuse of the attorney-client privilege, see Deborah L. Rhode, David Luban, Scott L.
} 
the public, the industry created a "research institute" that commissioned scientific studies of tobacco's health effects - but it released only studies that aided its disinformation campaign (blowing smoke, one might say), and suppressed the rest. Scientific reports were routed through industry lawyers rather than sent directly to management, so that lawyers could assert the attorney-client privilege to shield them from discovery in lawsuits against Big Tobacco. The scheme came to light only in the late 1990s, after forty years of successful stonewalling. The result was an adverse legal ruling piercing the attorney-client privilege because of Big Tobacco's fraudulent intent, leading to the release of millions of pages of damning documents, and forcing a multi-billion dollar settlement. The prolonged industry effort, which combined lying, half-truths, decoy flooding, and suppression using a legitimate legal device, is a perfect illustration of epistemic malevolence at work, but also moral malevolence.

Lying, suppression, decoy flooding. One of Arendt's keenest observations is that the result is not deceit but rather "a peculiar kind of cynicism - an absolute refusal to believe in the truth of anything, no matter how well this truth may be established." 89 As she put it in an interview, "if everyone always lies to you, the consequence is not that you believe the lies, but that no one believes anything at all anymore." 90 Kant was perhaps the first to argue that a generalized practice of lying undermines the credibility of all statements. ${ }^{91}$ Arendt takes the argument a step further, and tells us what it would be like to live in that world.

It's essential to distinguish between the producers, distributors, and consumers of disinformation, and also to ask the separate question of whether producers and distributors actually believe what they are saying. Epistemic malevolence - the desire to defeat truth and frustrate truthseekers - is a vice of producers and distributors of propaganda, not consumers. It may seem obvious that producers of fake facts don't believe their own fabrications, but that is not always the whole story. Of course whoever wrote the Protocols of the Elders of Zion knew it was fake, but they may well have believed in the reality of a world Jewish conspiracy. This was Josef Goebbels's view. He believed the Protocols were fake; they nevertheless represented "the inner, but not the factual truth." 92 To take a more recent example, Jürgen Elsässer, the editor of a far-right German magazine that vigorously promotes QAnon, "does not believe in a

Cummings, and Nora Freeman Engstrom, Legal Ethics $8^{\text {th }}$ ed. (Foundation, 2020), 27880.

${ }^{89}$ Arendt, "Truth and Politics," in Between Past and Future, 257.

${ }^{90}$ Interview with Roger Errera, in Thinking Without a Bannister, 491.

${ }^{91}$ Kant, "On a supposed right to lie from philanthropy," in Mary J. Gregor, trans. \& ed., Kant: Practical Philosophy (CUP, 1996), 8:426, p. 612.

${ }^{92}$ Quoted from Goebbels's diaries in Evans, Hitler Conspiracy Theories, 32. Goebbels is an archetypal distributor as well as producer. 
conspiracy of pedophile elites, preferring to look at it as 'allegories." ${ }^{\prime 93}$ But he may believe in whatever liberal elite wickedness these phantasms are allegories for. Ideologists presumably believe their own ideology, and may regard their factual fabrications as "true enough."

And we must not discount the possibility that producers are taken in by their own productions. As I noted earlier, conspiracists often come equipped with buckets of "evidence" - small, innocent or not-so-innocent facts that to a suitably attuned mind add up to proof. Their basic inference pattern is that if what they suspect could happen, their smatterings of evidence "prove" that it did happen. (If voting machines could be hacked they were hacked.)

The logician A. N. Prior coined the label "runabout inference ticket" to describe a bogus rule of reasoning that can get you from anywhere to anywhere else - and "my conspiracy theory could explain my scraps of evidence, therefore it does explain it" is a perfect runabout inference ticket. ${ }^{94}$ Let's look at an example I mentioned earlier: the theory (au courant when I wrote these words) that Bill Gates somehow planned to insert mindcontrol microchips in millions of people through covid vaccinations. Here is the evidence:

- Gates gave pre-covid speeches about the need for population control to reduce climate threats. Gates noted that improving health in developing countries is a promising strategy, because better health has been shown to correlate with lowered birth rates. Among the health measures Gates favors are vaccination and women's access to birth control. The ineluctable conclusion, as one conspiracy video warns: "Bill Gates Vaccines are used for depopulation." ${ }^{\circ 5}$

- In 2017 Gates gave a speech in Davos warning against nations' unpreparedness for "an epidemic, either naturally caused or intentionally caused." This video drew dire comments, especially post-covid: "He has not warned; he has planned." "He dropped the 'intentionally' several times PAY ATTENTION. He is giving us hints." "Really easy to predict the future when you write the script." "Why the hell would you even say intentional if you didn't know anything? That implies evilness or maybe he chooses not to admit. Pure evil." "He's working on injections with a microchip to monitor population." 96

\footnotetext{
${ }^{93}$ Quoted in Benhold, "QAnon is Thriving in Germany."

${ }^{94}$ A. N. Prior, "The Runabout Inference Ticket," Analysis 21(2) (1960): 38-39.

95 Bill Gates Vaccines are used for depopulation, YouTube (Nov. 13, 2017). https://www.youtube.com/watch? $\mathrm{v}=\mathrm{eNmj} 6 \mathrm{Ug}$-a 4A. The video's producer is not identified. The explanation of the odd-sounding correlation between better health and lower birth rates seems to be that with better health for mothers and children, poor parents don't feel the pressure to have additional babies as "insurance."

96 Bill Gates has a warning about deadly epidemics, YouTube (Jan. 22, 2017), https://www.youtube.com/watch?v=jDxb21qIilM.
} 
- Then came a February 2020 announcement by the Bill \& Melinda Gates Foundation that it would commit $\$ 100$ million "for the global response to the novel coronavirus," including vaccine research. ${ }^{97}$

- Next: a scientific paper on a novel technology to trace who has or has not received vaccinations, by using quantum dots delivered to skin via "microneedle patches" - research supported by none other than the Gates Foundation. ${ }^{98}$

- The icing on the conspiracy cake was a 2018 patent application by Microsoft researchers for a method to link body activity data to blockchain. ${ }^{99}$

There you have it. Population control via vaccination and contraception. Gates hinting at intentional epidemics - at Davos, no less, known by all to be Ground Zero for international elite conspiracies. Covid vaccine research and a "global" response. Microneedles. Vaccine tracing. Gates Foundation. Microsoft. Blockchain monitoring body activity. It's all there, once you stitch the pieces together on a backcloth of antivaxxing, climate denialism, and political resentment. One result: almost 700 thousand people petitioned the White House to investigate the Gates Foundation for medical malpractice and crimes against humanity. ${ }^{100}$

The key point is that whoever launched the conspiracy theory may actually believe it, or sort of believe it, because their epistemic stance equips them with a runabout inference ticket that converts suspicions to certainties, catalyzed by these tantalizing smidgens of "evidence." In just the same way, Stalin and Kaganovich may actually have believed that reactionary peasants were sabotaging the Ukrainian harvest. Peasant hostility to collectivized farming was a known fact, the bad harvest was a known fact, and the infallibility of the Party line provided the inference ticket.

97 Bill \& Melinda Gates Foundation Pressroom, "Bill \& Melinda Gates Foundation Dedicates Additional Funding to the Novel Coronavirus Response," https://www.gatesfoundation.org/Media-Center/Press-Releases/2020/02/Bill-and-

Melinda-Gates-Foundation-Dedicates-Additional-Funding-to-the-Novel-CoronavirusResponse.

${ }^{98}$ Kevin J. McHugh et al., "Biocompatible near-infrared quantum dots delivered to the skin by microneedle patches record vaccination," Science Translational Medicine 11(523), Dec. 18, 2019, https://stm.sciencemag.org/content/11/523/eaay7162.abstract. The technology was tested on rats, not human beings, and microneedles have nothing to do with microchips.

99 Dustin Abramson et al., "Cryptocurrency system using body activity data," https://patents.google.com/patent/WO2020060606A1/en. On the conspiracy theory, see Marie Huillet, "Ex-CIA agent drags Microsoft's crypto-patent into right-wing conspiracy," Cointelegraph.com, Sept. 10, 2020, https:/cointelegraph.com/news/ex-cia-agent-dragsmicrosofts-crypto-patent-into-right-wing-conspiracy.

100 Petition, Apr. 10, 2020, https://petitions.whitehouse.gov/petition/we-callinvestigations-bill-melinda-gates-foundation-medical-malpractice-crimes-againsthumanity. 
What we see, therefore, is something surprising: that epistemically malevolent actors can have varying degrees of belief in their own fabrications, ranging from clear-eyed knowledge that the fabrications are lies, to belief that they are "true enough" or allegorically true, to belief (based on runabout inference tickets) that they are true full stop. But, regardless of the purveyors' degree of credence, their fabrications directly aim to defeat factual truth, and that makes their propaganda epistemically malevolent.

\section{Epistemic insouciance and culpable credulousness}

Closely related to epistemic malevolence - and crucial to understanding Arendt's insights - is a different vice, what Cassam calls epistemic insouciance:

an indifference or lack of concern with respect to whether their claims are grounded in reality or the evidence. Epistemic insouciance means not really caring much about any of this .... Epistemic insouciance is a particular form of not giving a shit. ${ }^{101}$

His prime examples are Brexit campaigners including Boris Johnson, who in his pre-political career as an EU-baiting journalist was fired twice for lying and "laughed it off when it was shown that his stories bore no relation to reality." 102

Harry Frankfurt defines bullshit as speech in which the speaker doesn't care if it is true or false. ${ }^{103}$ Epistemic insouciance is the vice associated with bullshitting. Whereas epistemic malevolence is willful deceptiveness, the bullshitter's mental state is what criminal lawyers call recklessness: conscious disregard of a substantial and unjustifiable risk. In mass propaganda, it is a double risk: the risk of deceiving others, and, as Arendt rightly warns, the risk of devaluing truth itself and inducing a kind of all-consuming cynicism that devours common sense.

Epistemic insouciance comes in many flavors. Its motivation can be political, as with the Brexit campaigners. Some among them might truly believe the Brexit ideology; others may not, and simply sought power. Among the epistemically insouciant we also find apolitical grifters who make money off of clicks, and who understand that in the market for clickbait, bullshit sells. Some bullshit purveyors may not recognize the cynicism their decoy flooding produces in their audience; others may recognize it and regard it as regrettable collateral damage in pursuit of political victory. And some may actively seek to sow this kind of cynicism, either for political gain or for nihilistic amusement.

\footnotetext{
101 Vices of the Mind, 79.

102 Ibid.

${ }^{103}$ Harry G. Frankfurt, On Bullshit (Princeton University Press, 2009).
} 
This is supply-side insouciance - that is, the epistemic insouciance of propagandists. But there can also be epistemic insouciance on the demand side, that is, on the part of propaganda's targets. Of course, these are the duped, not the dupers. That doesn't make consumers innocent victims, however, if they are willfully or recklessly gullible rather than innocent and naive. Their stance toward the propaganda is receptive, not guarded - in Arendt's words, they are "ready at all times to believe the worst, no matter how absurd." 104

Arendt's insight is that they could choose a more epistemically vigilant stance, but willfully or recklessly prefer not to. Then, when the propaganda they've accepted turns out to be false, they insulate themselves from responsibility for accepting it, either by grudgingly thinking "it's true enough" or - as Arendt argues - by cynically rationalizing that it's all lies and cheating out there anyway. Instead of feeling betrayed by the liar, they like him because he knows how to play the cheating game, and now they are in on the joke.

Whether their response to propaganda is "it's true enough" or "it's all cheating anyway," the result is a radical devaluation of facts and common sense. Here, the maxim of common sense that epistemic insouciance jettisons is "Fool me once, shame on you; fool me twice, shame on me." In its place, the motto seems to be "fool me once, good for you; fool me twice, fine with me. It's all cheating anyway, and I like your bullshit better than the other side's bullshit."

"It's all cheating anyway" cynically devalues truth, and in that way becomes a handy excuse for what I will call culpable credulousness. Mere gullibility needn't be culpable. It can be a sign of an innocent and trusting nature, a character trait that is more touching than vicious. Culpable credulousness is different. It intentionally devalues factual truth as an excuse for letting oneself be fooled - as long as it's "our side" that is doing the fooling.

Recast in these terms, the epistemic stance Arendt calls "a mixture of gullibility and cynicism" would more properly be called a mixture of culpable credulousness and cynicism. The cynicism is at once the product and the source of the credulousness: it is the product, because credulous individuals allow themselves to be fooled again and again, which would be enough to make anybody cynical. It is the source, because the cynical premise that every statement in the public sphere is a lie excuses the consumer who keeps coming back for more. Devaluing truth as an excuse for one's own credulousness is precisely what makes credulousness culpable.

104 OT, 382. Here, I follow Cassam in using "stance" to denote a chosen attitude toward believings; he distinguishes stances from postures, which are involuntary. Naïve trust seems more like a posture. 
This circular and self-reinforcing process gives meaning to the second epigraph to this paper: "Totalitarian propaganda can outrageously insult common sense only where common sense has lost its validity." 105 Common sense has lost its validity when a large segment of the populace has become so bitter and disaffected that it no longer values holding factual truths in common with others.

\section{§7. Rules of common sense}

The virtue corresponding to the vice of epistemic insouciance is epistemic vigilance (a phrase I borrow from Dan Sperber and his coauthors ${ }^{106}$ ). Given that by far the greater part of what we know comes from other people, vigilance against being misinformed or misled by them is an indispensable trait. It requires us to evaluate testimony from others along the two dimensions of competence and honesty - asking the questions is my informant in a position to know that? And is my informant trying to fool $m e$ ? Experiments show that children already make such discriminations by age four, and likely even earlier. ${ }^{107}$ This suggests that just as the indispensable propensity to trust other people as sources of knowledge is hard-wired into our cognitive heritage, so is the counterbalancing trait of vigilance. An essential part of vigilance consists of following rules of common sense when someone tells us something that matters to us.

Arendt would certainly agree that there are rules of common sense. Recall that Arendt speaks of "general contempt for even the most obvious rules of common sense," and the first page of Origins warns that "never have we depended so much on political forces that cannot be trusted to follow the rules of common sense."

Rules of common sense are not inexorable laws of logic; they are rules of thumb. Perhaps the most famous rule of common sense is Occam's Razor, understood here as the principle that baroque or arcane explanations should be rejected in favor of simple ones if the simple ones cover the facts. ${ }^{108}$ But there are others. We have already seen a few examples. One such rule is that if it's too good to be true, it isn't true:

If, for instance, all the "confessions" of political opponents in the Soviet Union are phrased in the same language and admit the same motives, ... common sense tells us that it is

\footnotetext{
${ }^{105}$ OT, 352.

${ }^{106}$ Dan Sperber, Fabrice Clément, Christophe Heintz, Olivier Mascaro, Hugo Mercier, Gloria Origgi, and Deirdre Wilson, "Epistemic Vigilance," Mind and Language 25 (2010): 359-93.

${ }^{107}$ Ibid., 371-73.

${ }^{108}$ For a cute application of Occam's Razor to presidential election conspiracies in 2020, see David von Drehle, "How this medieval philosopher would debunk Trump's election claims," Washington Post, Dec. 11, 2020, https://www.washingtonpost.com/opinions/how-this-medieval-philosopher-woulddebunk-trumps-election-claims/2020/12/11/0bd1aade-3bd5-11eb-98c425dc9f4987e8 story.html.
} 
precisely their consistency which is out of this world and proves they are a fabrication. ${ }^{109}$

And if a supposed conspiracy would require flawless coordination and perfect secrecy by hundreds of otherwise unconnected people, common sense tells us that it didn't happen.

Common sense also looks at the competence and honesty of sources. If informants claim to know something they are in no position to know, a rule of common sense instructs us to discount what they say. And if an informant has repeatedly lied in the past and been exposed, don't believe that informant the next time. (Fool me once, shame on you; fool me twice, shame on me.) Holding self-serving assertions to a higher standard of proof than adverse admissions is another rule of common sense. - Obviously, this list could easily be expanded. The question is, if epistemic vigilance is hardwired into us, as it seems to be, how can rules of common sense get disabled on a mass scale?

As we've seen, Arendt blames it on a kind of willful cynicism and insouciance brought on by the collapse of traditional society - a political explanation with moral overlay. But there are more innocent non-political explanations as well. An inherent problem is that the everyday mechanisms of vigilance we learn from childhood are geared to face-to-face interactions, and they don't scale up to entire populations. Sperber and his co-authors identify at least four points of mismatch, none of which have to do with atomization in mass society:

1. The longer the chain of transmission, the more likely that the facts being transmitted are garbled; and we usually have no idea how long the chain is when a friend passes along something interesting that the friend learned from someone else. We are likely to judge that information as though our trusted friend is the source, rather than recognize it as the final link in a long telephone game.

2. Furthermore, ordinary vigilance about sources doesn't work when the source is unidentifiable, and the intelligence is passed along merely because "a lot of people are saying ...."

3. The normal human pleasure of spreading interesting news, which is benign and even indispensable in everyday life, means that fake news will often come to us from multiple seemingly-independent sources that confirm each other, even though it originated with a single producer.

4. And the conformist pressure to believe what a large group believes - or at least, to accept what they accept - is surely just as strong as conformist pressure to behave as the group behaves. ${ }^{110}$

109 OT, 352.

${ }^{110}$ Sperber et al., 379-82. 
All this would be true regardless of Arendtian "gullibility and cynicism." All the same, Sperber and his co-authors concur that "empty creeds" can invade whole populations when accepting them defines group identities. They argue that in such cases the acceptance is not strictly speaking epistemic, but what they mean is that acceptance is not the same as belief - which is exactly Arendt's point when she writes that the true goal of propaganda is not persuasion but organization. For that reason, I think Sperber and his co-authors misstate their point when they say that tribalist belief-acceptance is not epistemic. The practice of accepting propositions for purely tribalist reasons defeats truth and knowledge, and that is very much an epistemic vice. And when empty creeds invade whole populations common sense has, as Arendt puts it, lost its validity.

\section{$\S 8$. The collapse of moral common sense}

To conclude, I want to return to the loss of moral common sense. Earlier I argued that losing moral common sense does not require a radical transvaluation of values where good is evil and evil is good - although we'll see shortly that Arendt occasionally and mistakenly spoke this way as a figure of speech. To be sure, Nazi fanatics boasted about "a completely new spirit of Germanic coldness," but that kind of blather is not required for the loss of moral common sense. ${ }^{11}$

All that is required is false factual beliefs about existential threats to things you hold dear. If you believe that entire races or classes are your deadly enemies, or that the very existence of your society is menaced by secret conspiracies, then killing the enemies will seem like justified selfdefense. And even people who aren't convinced about existential threats may acquiesce if the falsehood comes to be the prevailing opinion, promoted by leaders and hyped by their propaganda machine; they will do so on the shoulder-shrugging theory that if there's so much smoke perhaps there really is fire. In short, the collapse of factual common sense can topple moral common sense by conjuring up fictitious enemies and triggering selfdefense. This requires no transvaluation of values, only a supersense interpretation of facts, coupled with the common belief that deadly threats can justify actions in self-defense that would ordinarily be forbidden.

One of Arendt's keenest insights is that in such a toxic epistemic environment rules of thumb we use to identify wrongdoing fail, and in failing will bring about the collapse of morality. In Eichmann in Jerusalem and elsewhere, Arendt discusses several examples of commonsense rules of epistemic vigilance that failed in totalitarian regimes.

The first, and most fundamental, such rule is to look around at what conduct respectable and decent people treat as normal. Aristotle rightly observes that young people learn to be virtuous by imitating the virtuous,

111 The quoted phrase comes from a letter written at the start of the war by a young Luftwaffe pilot to an anti-Nazi friend, who was horrified by it. Friedrich Percyval ReckMalleczewen, Diary of a Man in Despair, trans. Paul Rubens (Macmillan, 1970), 89-91. 
not by reasoning their way to virtue; and although we eventually graduate from imitation to making our own judgments, he holds that we actually have no better measure of right and wrong than looking to "the good person insofar as he is good." "12 If respectable people go about their business in the normal way, we may assume that things are not as bad as they seem. This observation is connected with the bystander effect familiar from social psychology: if the other bystanders to a disturbing event seem unperturbed, then we are less likely to be perturbed. And the bystander effect may be reciprocal, until a saturation point is reached and the abnormal becomes normal.

In any case, it is all too easy to equate the conventional views of the majority with common sense. As a slightly comical example, a theologian once commented that "the average layperson today has too much common sense" to doubt the authenticity of Christian miracles. ${ }^{113}$ Now by definition, a miracle is an event that defies common sense; that is what makes it a miracle. But we understand exactly what the theologian meant: Christian scholars who deny the historical accuracy of the Gospel are fringe, and the multitudes who believe in miracles are the mainstream. Mainstream belief is common sense.

But conventions can be fickle and quickly swayed by propaganda. If the reigning ideology is evil, someone trying to calibrate their own moral compass by checking it against the weathervane of mainstream opinion is lost. This is central to Arendt's diagnosis of Eichmann: "His conscience was indeed set at rest when he saw the zeal and eagerness with which 'good society' everywhere reacted as he did. ... [H] is conscience spoke with a 'respectable voice,' with the voice of respectable society around him."'114 And it was not Eichmann alone. Even Dr. Josef Mengele, the "angel of death" conducting infamous human experiments at Auschwitz, was not the

112 N.E., Bk. 10 ch. 5, 1176 a17 (Irwin trans.). Arendt calls attention to this striking sentence in "Socrates," in The Promise of Politics (Schocken Books, 2009), 24. On moral education, 1179b4-31. See M. F. Burnyeat's superb “Aristotle on Learning to Be Good," in Amélie Oksenberg Rorty, ed., Essays on Aristotle's Ethics (University of California Press, 1980): 69-92. See in addition Rosalind Hursthouse's very persuasive argument that "Do what the virtuous do," which opponents of virtue ethics think is useless because we would already need to know what virtue is to identify our virtuous role models, is in fact just as useful as "Do what has the best consequences" and "Do what correct moral rules or principles" dictate. Hursthouse, On Virtue Ethics (Oxford University Press, 1999), 25-31. I think "Do what the virtuous do" is often more concrete and useful than its competitors. In hard choices, I'm pretty sure that I have a better idea whose advice to seek because I trust their judgment than I have about what consequences to predict or which of two clashing moral rules applies.

113 Bill Broadway, "What Really Happened to Jesus?”, Washington Post, April 6, 1996, https://www.washingtonpost.com/archive/local/1996/04/06/what-really-happened-tojesus/55dda1b6-3a24-48e6-af87-d38a2a916868/.

114 Hannah Arendt, Eichmann in Jerusalem: A Report on the Banality of Evil (Viking Books, 1964), 126. 
sadistic monster of legend; he was doing respectable normal science in the academic community of Third Reich genetics and anthropology. ${ }^{115}$

In addition to looking up and looking around at other people, we ask "Is this an exception to a moral rule, or is it prescribed by the rule itself?" The exceptional status of an act is a second alarm bell warning us that the act is presumptively wrong. It signals deviance, and deviance is a name we give to wrongdoing. But this mechanism fails when the prevailing morés have made exceptions into rules. "I am alluding, of course, to what happened in Nazi Germany and, to some extent, also in Stalinist Russia, when suddenly the basic commandments of Western morality were reversed: in one case, 'Thou shalt not kill'; in the other, 'Thou shalt not bear false witness against thy neighbor." "116 In the SS, "Thou shalt kill" became the rule, and "Thou shalt not kill" was the deviation.

As I remarked above, these striking formulations sound like Arendt is describing a transvaluation of values, but I don't think that is what she is getting at. If it is, it's a mistake. A better way to understand the phenomenon is to recognize that most rules of conduct have exceptions for emergencies. For example, most would agree that "Thou shalt not kill" has an in-built exception for killing in self-defense against deadly threats. By redefining the factual situation as one of existential struggle against enemies, the totalitarian regimes shifted the boundary of who counts as a mortal threat, and in that way they swapped the persecution of innocents out of the categories of sin and crime and into the category of legitimate self-defense. Although Arendt frames this as the reversal of rule and exception, it's more accurate to describe it as redrawing the boundary of the rules to expand the category of exceptions.

This is an important point. Arendt marvels bitterly at how quickly and frictionlessly Germany adopted a criminal morality - adding that it should not reassure us about morality that after the war it was equally easy to turn morality upright again. ${ }^{117}$ My suggestion here is that morality never did turn upside down; rather, what turned upside down was a factual assessment of whether the world was now in a state of exception. Factuality, not morality, turned upside down.

\footnotetext{
115 "The notion of Mengele as unhinged, driven by demons, and indulging grotesque and sadistic impulses should be replaced by something perhaps even more unsettling. ... The science he pursued in Auschwitz ... was not anomalous but rather consistent with research carried out by others in what was considered to be the scientific establishment. ... It is easier to dismiss an individual monster than to recognize the monstrous that can emerge from otherwise respected and enshrined institutions." Marwell, Mengele: Unmasking the "Angel of Death", 115-16.

${ }^{116}$ Hannah Arendt, The Life of the Mind: Thinking (Houghton Mifflin Harcourt, 1971), 177; Eichmann in Jerusalem, 150; 290-92.

${ }^{117}$ Hannah Arendt, "Personal Responsibility Under Dictatorship," in Responsibility and Judgment, ed. Jerome Kohn (Schocken Books, 2003), 24-25; "Some Questions of Moral Philosophy," in Responsibility and Judgment, 54-55.
} 
Either way, however, her shrewd point remains that detecting evil by its deviance no longer becomes a reliable rule of moral common sense. Legitimate exceptions don't count as deviance.

A third hallmark we use to recognize evil is temptation. A person is tempted to stray sexually - forbidden fruit! Or to break an inconvenient promise (forbidden fruit!), or to lie your way out of trouble (forbidden fruit!). But the converse is also true: the very fact that an ordinary human being is not in the slightest bit tempted to murder innocent people takes away this tell-tale sign by which someone, ordered to kill by his superiors, recognizes evil.

Evil in the Third Reich had lost the quality by which most people recognize it - the quality of temptation. Many Germans and many Nazis, probably an overwhelming majority of them, must have been tempted not to murder, not to rob, not to let their neighbors go off to their doom .... But, God knows, they had learned how to resist temptation. ${ }^{118}$

A fourth mechanism is even subtler. The mass murders and enslavements committed by the Third Reich were hedged around with bureaucratic restrictions on who, when, where, and how. Participants could see that "by no means all was permitted" even in the Holocaust. ${ }^{119}$ That made it appear that there was nothing nihilistically cruel about mass murder on a vast scale. It lacked the "anything goes" earmark of casting moral restraint to the winds. ${ }^{120}$ A good example is the strange, revealing story of SS judge Konrad Morgen, analyzed in the illuminating moral biography by Herlinde Pauer-Studer and David Velleman. ${ }^{121}$ Morgen was a strict rule-oflaw prosecutor in the SS's internal justice system. He zealously prosecuted unauthorized looting, killing, and corruption by SS men in death camps but failed to notice how anomalous that was in a setting where he was surrounded by murder and looting on an industrial scale.

In sum, Arendt calls our attention to four rules of moral common sense to recognize wrongdoing (although she doesn't use that terminology, and doesn't discuss all of them in one place):

1. It's wrong if most respectable people around me say it's wrong and behave as if it's wrong.

\footnotetext{
118 Eichmann in Jerusalem, 150.

119 "Personal Responsibility Under Dictatorship," 42.

${ }^{120}$ Not that the Holocaust was heavily regulated in on-the-ground practice. One of the revelations at the trial of Auschwitz personnel that drew Arendt's bitterest anger was how at every moment life and death was up to the whims and passing moods of the guards and officials. They operated in an environment where "anything goes" was the actual rule and Arendt had no difficulty concluding that they were moral monsters, far removed from the banality of evil.

${ }^{121}$ Herlinde Pauer-Studer \& David Velleman, Konrad Morgen: The Conscience of a Nazi Judge (Palgrave-Macmillan, 2015).
} 
2. It's wrong if it deviates from a generally accepted social rule.

3. It's wrong if I feel a temptation toward it, coupled with (or recognized by) the lurking sense that I shouldn't give in because the fruit is forbidden.

4. It's wrong if it is part of an antinomian practice, that is, a practice in which it seems as though all restraint has been cast off and all is permitted.

In criminal regimes, none of these rules works as advertised. Those relying on them would be unable to distinguish authentic morality from the twisted conventional morality of the regimes. We can generalize from the case of criminal regimes: any powerful social institution that manages to set up a twisted system of conventional morality based on "facts" that defy common sense will make it hard for those within it to tell right from wrong. Mechanically applying the everyday rules of moral common sense to fictitious facts speeds us on our way to Hell. 